Proc. Estonian Acad. Sci. Biol. Ecol., 2006, 55, 2, 149-159

\title{
Influence of cement clinker dust on carbohydrates in needles of Scots pine shortly after the application
}

\author{
Jaan Klõšeiko* and Mari Tilk \\ Department of Ecophysiology, Institute of Forestry and Rural Engineering, Estonian University of \\ Life Sciences, Viljandi mnt. 18B, 11216 Tallinn, Estonia \\ Received 9 December 2005, in revised form 3 March 2006

\begin{abstract}
Clinker dust could be used as an amendment of forest soils to improve the nutrition of trees. Soil $\mathrm{pH}$, needle carbohydrates (glucose, fructose, sucrose, starch), and chlorophyll fluorescence (Genty parameter) were measured about two months after the application of $0.5 \mathrm{~kg}$ clinker dust $\mathrm{m}^{-2}$ and in a reference treatment with a slow release $\mathrm{N}, \mathrm{P}, \mathrm{K}, \mathrm{Mg}$ fertilizer in a Scots pine plantation. The spatial variation of the soil $\mathrm{pH}$ values between the sampling locations and soil layers was not increased by the clinker dust treatment although small-scale heterogeneity in the distribution pattern of dust was observed. The photosynthetic parameters were measured by chlorophyll fluorescence and were not affected by treatments. Dust and fertilizer reduced significantly the concentration of hexoses (glucose + fructose) in 1-year-old needles.
\end{abstract}

Key words: fructose, glucose, nutrient recycling, soil liming, starch, sucrose.

\section{INTRODUCTION}

Cement clinker dust is recommended for the liming of acid and nutrient-poor agricultural soils (Järvan, 2003). The spreading of clinker dust on forest soils is receiving attention as a measure of waste disposal and improvement of nutrient status. Clinker dust is alkaline and contains several plant nutrients $(\mathrm{K}, \mathrm{Mg}, \mathrm{Ca}$, microelements) at about the same element ratios as wood ash. However, the response of forest soils to application of wood ash may differ from that of the agricultural soils (Kahl et al., 1996). Eriksson et al. (1998) found that in some layers of soil the $\mathrm{pH}$ was increased and in some layers it was decreased shortly

${ }^{*}$ Corresponding author, jkl@rmk.ee 
after the application of wood ash onto forest soil. After the spreading of clinker dust, nutrient availability to trees could be abruptly changed. The treatment may increase spatial and temporal differences in the soil characteristics. Soil $\mathrm{pH}$ affects significanly the uptake of nutrients and changes in carbohydrate metabolism counteract the altered nutrient availability or adjust to the mobilization of nutrient reserves in trees. Potassium and magnesium, in turn, increase photosynthesis and favour carbohydrate partitioning (Marschner et al., 1996).

Characteristics of primary photochemistry measured by the chlorophyll fluorescence are often used to quantify the stress of plants. In sugar maple, the photosynthetic electron transport rate determined on the basis of the chlorophyll fluorescence is higher in conditions of a balanced base cation nutrition than in poor acidic soils (St. Clair \& Lynch, 2005; St. Clair et al., 2005).

Carbohydrate concentrations in conifer needles interact with the mineral nutrition and photosynthesis. Clinker dust and wood ash applications appear to decrease the fructose and glucose concentrations in needles, while the sucrose concentration is less affected by the modified nutrition (Klõšeiko, 2003). Increased release of potassium and magnesium enhance the accumulation of starch when there has not been a severe deficiency of these nutrients, because the photosynthesis is increased more than the translocation of carbohydrates from needles (Ericsson et al., 1996). Also, composite $\mathrm{Mg}, \mathrm{Ca}$, and $\mathrm{K}$ fertilization increases starch reserves in sugar maple leaves in summer (Liu et al., 1994). A few experiments with clinker dust and wood ash show various changes or no alteration in the needle starch levels (Klõšeiko, 2003).

The aim of the present study was to characterize the response of soil $\mathrm{pH}$ and needle physiological traits of Scots pine to clinker dust shortly after the surface application to soil. Small-scale spatial variability in the soil $\mathrm{pH}$ could be increased by the clinker dust treatment because of the salt effect, which according to the study by Eriksson et al. (1998) causes temporarily large $\mathrm{pH}$ differences between the upper layers of soil. A reduction in the foliar concentration of glucose and fructose was found in several previous experiments with wood ash and clinker dust 1-2 years after the treatment (Klõšeiko, 2003). By that time the $\mathrm{pH}$ of soil is more or less stabilized. The reasons of the reduction in the concentration of hexoses in foliage are probably associated with the improved nutrition of trees by fast uptake of some nutrients originating from clinker dust, while the altered soil $\mathrm{pH}$ has less influence on the concentration of hexoses in needles.

\section{MATERIAL AND METHODS}

Site and treatments

The Scots pine (Pinus sylvestris L.) studied grows on a nutrient-poor sandy soil of Calluna-site-type located $20 \mathrm{~km}$ south-east of Tallinn $\left(59^{\circ} 18^{\prime} \mathrm{N}, 24^{\circ} 43^{\prime} \mathrm{E}\right)$. The stand was established in 1983 by sowing. The landform of the site is flat 
glacial plain with ground vegetation consisting of Calluna vulgaris (L.), Vaccinium vitis-idaea (L.), lichens, mosses, and small pines.

The stand had been thinned in the autumn before the trial and the cut trees were removed from the study areas at least $5 \mathrm{~m}$ away. The trial plan for the experiment had three treatments with four replications (15-25 m apart), each of which was a circular plot with an area of $120 \mathrm{~m}^{2}$ covered by 58-147 trees with heights over $1.6 \mathrm{~m}$. Completely random distribution of treatments among the plots was used. Three treatments were applied: (1) cement clinker dust $\left(0.5 \mathrm{~kg} \mathrm{~m}^{-2}\right)$, (2) N, P, K, Mg fertilizer $\left(0.05 \mathrm{~kg} \mathrm{~m}^{-2}\right)$, and (3) a control (untreated plots). The clinker dust and the fertilizer were both spread by hand on 25 May 2005 around the time of bud break.

The clinker dust $(\mathrm{pH} 13.0$ in 1:5 dust:water, w/w) originated from Kunda cement plant and contained $0.13 \% \mathrm{P}, 3.0 \% \mathrm{~S}, 2.0 \% \mathrm{Al}, 45.6 \% \mathrm{Ca}, 0.001 \% \mathrm{Cu}$, $1.5 \% \mathrm{Fe}, 4.9 \% \mathrm{~K}, 2.1 \% \mathrm{Mg}, 0.1 \% \mathrm{Na}, 0.007 \% \mathrm{~Pb}$, and $0.003 \% \mathrm{Zn}$ according to the analyses by the laboratories of Kunda cement plant and the Estonian Environmental Research Centre, meeting the requirements of EVS-EN ISO/IEC 17025:2000 competence. The fertilizer was granulated and slow release Belles Saisons (Pokon \& Chrysal, Naarden, The Netherlands) containing 19\% N (6\% in the form of nitrate, $1.5 \%$ as ammonium- $\mathrm{N}$, and $11.5 \%$ as urea-N), $2.6 \% \mathrm{P}, 17.4 \% \mathrm{~K}$, and $1.8 \% \mathrm{Mg}$. The used clinker dust and fertilizer are accredited in the fertilizer registry by the Estonian Plant Production Inspectorate.

Before the treatments, when the age of the stand was 22 years, the mean height, diameter at breast height, and the interception of photosynthetically active radiation

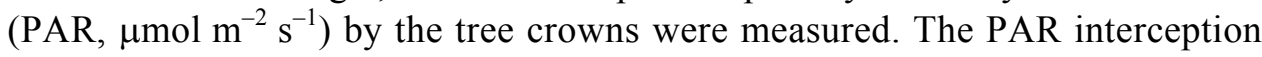
was evaluated with a ceptometer AccuPAR-80 (Decagon Devices, Pullman, USA). The height and diameter were measured in each plot on three trees. The mean height of trees was $4.4 \pm 0.6 \mathrm{~m}( \pm \mathrm{SD}, n=36)$. This height growth corresponds to the lower productivity site types IV-V by the classification in instructions for forest inventory in Estonia. The means of stand density on plot, tree growth parameters, and PAR interception were not significantly different between the three groups of plots before the application of treatments.

\section{Plant material}

Visual estimation showed that the shoots were longer on branches more open to the light. Variously shaded branch cuttings from the lower third of the crown with current-year and 1-year-old needles from 10 trees in each plot within $5 \mathrm{~m}$ radius were collected (on 21 July 2005), placed into plastic bags, and transported to the laboratory where the needles were separated. For the carbohydrate analysis needles were picked from the same shoots whose length was measured. The enzymes in needles were deactivated by microwave irradiation at $800 \mathrm{~W}$ for 
2-3 min (simultaneously three samples of $\sim 10$ g dry mass (d.m.)). Needles and shoots were completely oven-dried at $70^{\circ} \mathrm{C}$ for $48 \mathrm{~h}$.

To determine the influence of the lag between the cutting of branches and fixation of needles, test branches outside the trial plots were collected in parallel to the study material and fixed at $\sim 1 \mathrm{~h}$ intervals before the start, in the middle, and after the sample processing in laboratory. Concentrations of carbohydrates were little affected by the lag in fixation and the differences were nonsignificant.

\section{Soil}

Soil samples $\left(95 \mathrm{~cm}^{3}\right)$ were collected from 5 random locations on each plot from depths of 1-5 cm. The samples were divided into two layers: $1-3 \mathrm{~cm}$ and 3$5 \mathrm{~cm}$. Usually, the upper layer contained more organic matter and the lower layer more sand. The $\mathrm{pH}\left(\mathrm{H}_{2} \mathrm{O}\right)$ was measured from a mixture of dried soil and distilled water $(1: 2.5, \mathrm{v} / \mathrm{v})$ with a glass electrode InLab412 (Mettler-Toledo, Gießen, Germany) attached to a pH meter MP220 (Mettler-Toledo, Leicester, UK). The water content of the soil was calculated as the mass loss of soil during air-drying expressed in percentages.

\section{Chlorophyll fluorescence}

The primary photochemistry of photosynthesis was characterized by the Genty parameter $\Phi_{\mathrm{p}}=1-F / F_{\mathrm{m}}$, where $F$ is fluorescence under ambient light and $F_{\mathrm{m}}$ is maximum fluorescence under saturating light. Fluorescence was measured on intact trees at a height of 2-2.5 m above ground on the current-year needles with a fluorometer PPM-200 (EARS, Delft, The Netherlands). The same instrument records also PAR at the moment of fluorescence detection. Because of the changing cloud cover, which confounded the treatment effects, the Genty parameter was adjusted according to its dependence on PAR: $\Phi_{\text {adjusted }}=\Phi_{\mathrm{p}}$ $a \times \mathrm{PAR}+b$, where $a=-0.000148$ (the slope of linear regression, $p=10^{-15}$, $n=800$ ) and $b=0.087$ (chosen such that the overall means of $\Phi_{\text {adjusted }}$ and $\Phi_{\mathrm{p}}$ were equal). The linear photosynthetic electron transport (ETR, $\mu \mathrm{mol} \mathrm{m}^{-2} \mathrm{~s}^{-1}$ ) was estimated using incident light $\left(\mathrm{ETR}=0.5 \times \Phi_{\mathrm{p}} \times \mathrm{PAR}\right)$ (Maxwell $\&$ Johnson, $2000)$ and was adjusted according to linear regression on PAR analogously to the procedure applied for the adjustment of $\Phi_{\mathrm{p}}$.

\section{Carbohydrate analysis}

Grinding the dry needles with a vibrating ball mill MM200 (Retsch, Haan, Germany) produced fine powder, which was analysed enzymatically for carbohydrate concentration in the samples of $40-60 \mathrm{mg}$ according to Steen \& Larsson 
(1986). Extraction of soluble carbohydrates from the plant powder was performed with $40 \%$ ethanol in dilute Hepes buffer $(2 \mathrm{mM})$ at $40^{\circ} \mathrm{C}$ for $60 \mathrm{~min}$. Extracts were purified from polyphenols by insoluble polyvinylpyrrolidone $(\sim 50 \mathrm{mg})$.

Once the extraction suspensions were precipitated at $1900 \mathrm{~g}$ for $10 \mathrm{~min}$ on a bench centrifuge, hydrolysis with $37 \mathrm{mM} \mathrm{H}_{2} \mathrm{SO}_{4}$ at $80^{\circ} \mathrm{C}$ was applied in one part of the obtained solutions. The double amount of the glucose produced by the hydrolysis determined the sucrose concentration.

Starch determination was based on the principle of AACC Method 76.13 (Total starch assay procedure, 1998) scaled to $10 \mathrm{~mL}$ volume in test tubes. Soluble carbohydrates from the precipitate were removed with $40 \%$ ethanol. The precipitate, which contains the starch, was pre-treated with dimethyl sulphoxide $(1.5 \mathrm{~mL})$ at $100^{\circ} \mathrm{C}$. Starch was hydrolysed in the first step with thermostable $\alpha$-amylase (162 U/mL; A-4551; Sigma-Aldrich, Steinheim, Germany), adding Hepes buffer $(2.2 \mathrm{~mL})$ with the enzyme, and in the second step with amyloglucosidase (235 U/mL; from Aspergillus niger; Merck, Darmstadt, Germany) to the glucose.

The glucose and fructose concentrations (including their hexose-6-phosphates) of different extracts were measured with the hexokinase and glucose-6-phosphate dehydrogenase indicator reaction using the auxiliary isomerization of hexose phosphates with phosphoglucose isomerase (Bergmeyer, 1988). The enzymes were obtained from Sigma-Aldrich (Steinheim, Germany). Needle carbohydrate concentrations were expressed in $\mathrm{mg}$ hexose units $\mathrm{g}^{-1} \mathrm{~d}$.m.

\section{Statistical tests}

Analysis of variance (ANOVA) was used to test the occurrence of effects of treatments on the means of the measured parameters. In $t$-test, separate variances were assumed when comparing further the mean of the clinker dust or the fertilizer treatments with the mean of the control. Regression analysis was applied for the estimation of the dependence of $\Phi_{\mathrm{p}}$ on PAR. The Pearson correlation coefficients $(r)$ were calculated between carbohydrates, mean shoot length, and the number of trees on a plot. Differences in variance between groups were estimated applying the Kruskal-Wallis test on the absolute values of deviations from the group mean. The tests were calculated with Systat 10.0 software for Windows using $p$-values $(p)$ to assess the statistical significance of differences. The significances of correlations were calculated with the permutation method (Manly, 1997).

\section{RESULTS}

Patches of clinker dust and brown coated fertilizer granules were visible during the collection of soil samples. The mean $\mathrm{pH}$ was significantly different only in the clinker dust treated soil, which had a lower $\mathrm{pH}$ compared with the 
control ( $t$-test, $p=0.011$ and 0.017 for soil layers $1-3 \mathrm{~cm}$ and $3-5 \mathrm{~cm}$, respectively) (Table 1). The soil reaction was highly variable between sampling locations, but it was correlated between the layers $\left(r=0.81, p=2.8 \times 10^{-15}, n=60\right)$. Larger variance was found among the samples from the fertilizer treated plots, where the soil $\mathrm{pH}$ ranged from 3.8 to 6.5 at both depths. Kruskal-Wallis comparison of the fertilizer influence on deviations with those of the untreated soil indicated $p=0.045$ and 0.0045 for soil layers from top to bottom $(n=20)$. In dust treated and untreated soils, the $\mathrm{pH}$ varied within $\sim 1.2$ units between the sampling locations without significant effect of dust on the deviations compared with the control.

Treatment effects on parameters of photosynthesis were nonsignificant. Differences in the means of the needle carbohydrate concentrations between treatments were found in older needles. The concentration of hexoses (glucose + fructose) in 1-year-old needles of clinker dust treated trees was $\sim 80 \%$ of the respective value in the untreated trees ( $t$-test, $p=0.0008)$ (Fig. 1). The fertilizer influence on hexoses was smaller, but still significant ( $t$-test, $p=0.008$ ). Fructose and glucose were affected equally as seen by the even level of their ratio. The sucrose concentration was most stable across treatments; only the differences between the age classes were significant. Though the fertilizer reduced the hexose concentration and the sucrose levels varied little, the ratio of sucrose to hexoses did not significantly increase in response to the fertilization ( $t$-test, $p=0.16$ ).

Needle starch was not affected by the treatments. The $p$-value according to ANOVA was 0.24 for 1 -year-old needles and 0.12 for current-year needles in respect to their starch concentration. Among the measured carbohydrates starch concentration showed the highest variability estimated by the ratio of standard

Table 1. Characteristics of soil and Scots pine shoots 57 days after the application of clinker dust or a slow release $\mathrm{N}, \mathrm{P}, \mathrm{K}, \mathrm{Mg}$ fertilizer to the forest soil (control = untreated soil). 1-yr. = previous year growth, c-yr. $=$ current-year growth. $\Phi_{\mathrm{p}}$ is Genty parameter and ETR is photosynthetic electron transport, both adjusted by the linear regression with the light level at the moment of fluorescence detection. $p=p$-value of the differences in means according to the analysis of variance $( \pm \mathrm{SD}$, $n=4)$

\begin{tabular}{l|c|c|c|c|c}
\hline \multicolumn{1}{c}{ Parameter } & Soil depth & Control & Clinker dust & Fertilizer & $p$ \\
\hline Soil pH & $1-3 \mathrm{~cm}$ & $4.5 \pm 0.0$ & $4.0 \pm 0.2$ & $4.6 \pm 0.4$ & 0.02 \\
& $3-5 \mathrm{~cm}$ & $4.7 \pm 0.1$ & $4.3 \pm 0.2$ & $4.9 \pm 0.4$ & 0.03 \\
Soil water, \% & $1-3 \mathrm{~cm}$ & $9.0 \pm 3.6$ & $12.3 \pm 3.5$ & $9.5 \pm 1.5$ & 0.32 \\
& $3-5 \mathrm{~cm}$ & $6.7 \pm 0.9$ & $5.6 \pm 2.7$ & $5.1 \pm 1.3$ & 0.46 \\
Shoot length, cm & $1-\mathrm{yr}$. & $6.2 \pm 0.1$ & $6.7 \pm 0.9$ & $6.1 \pm 0.5$ & 0.28 \\
& c-yr. & $6.3 \pm 1.4$ & $8.0 \pm 1.4$ & $7.1 \pm 0.9$ & 0.21 \\
$\Phi_{\mathrm{p}}$ & c-yr. & $0.60 \pm 0.04$ & $0.60 \pm 0.03$ & $0.61 \pm 0.01$ & 0.85 \\
ETR, $\mu \mathrm{mol} \mathrm{m}^{-2} \mathrm{~s}^{-1}$ & c-yr. & $158 \pm 16$ & $153 \pm 8$ & $159 \pm 8$ & 0.72
\end{tabular}


Hexoses

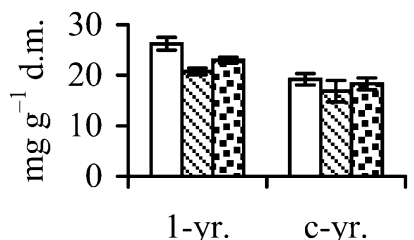

Fructose/Glucose

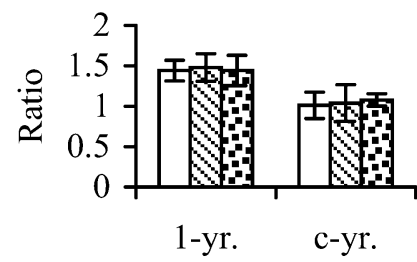

Starch

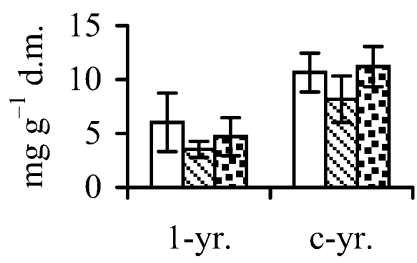

Sucrose

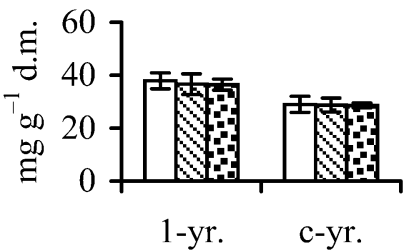

Sucrose/Hexoses

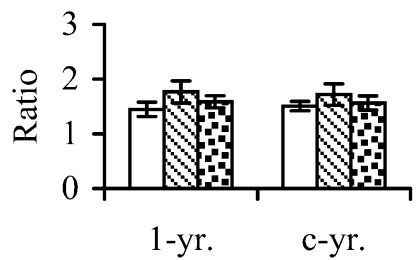

Total

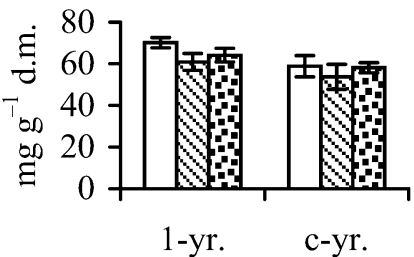

Fig. 1. Concentration of carbohydrates in Scots pine needles 57 days after the surface application of clinker dust (ruled bars) and slow release N, P, K, Mg fertilizer (dotted bars) onto forest soil and in Scots pine needles on untreated soil (open bars). Hexoses $=$ glucose + fructose, total $=$ hexoses + sucrose + starch, 1-yr. $=1$-year-old needles, c-yr. $=$ current-year needles, mean of four replicates, vertical bars $= \pm$ SD.

deviation to mean. Summing up hexoses, sucrose and starch, their total concentration was $\sim 90 \%$ of control in 1-year-old needles of dust and fertilizer treated trees ( $t$-test, $p=0.01$ and 0.02 , respectively).

The carbohydrate concentrations were partly associated with growth and stand characteristics. In the current-year needles the starch concentration tended to be lower on plots where the number of trees was higher $(r=-0.72, p=0.008, n=12)$. Also, the ratio of sucrose to hexoses correlated with the mean shoot length in all combinations of age classes (Fig. 2). 


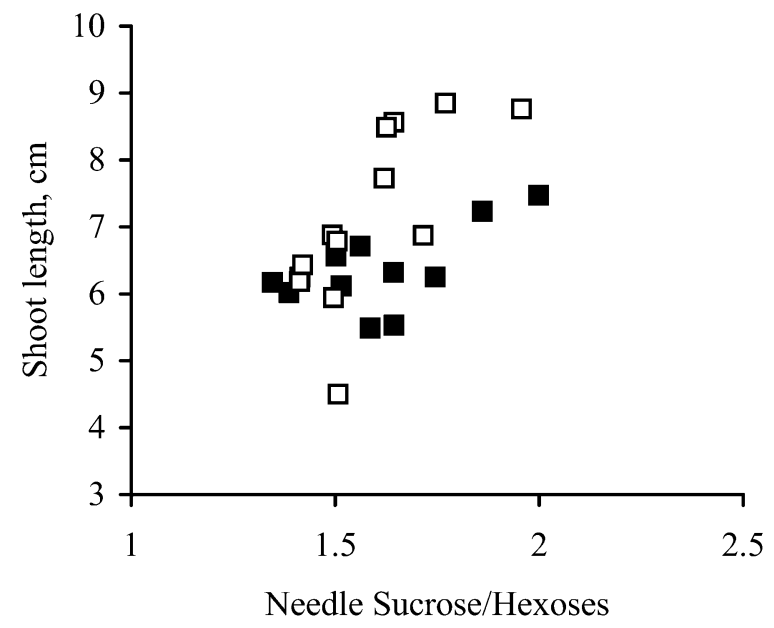

Fig. 2. Correlation between the mean shoot length and the ratio of sucrose to hexoses (glucose + fructose) in needles of Scots pine. Filled symbols correspond to 1 -year-old shoots $(r=0.60$, $p=0.039, n=12)$ and open symbols to current-year shoots $(r=0.72, p=0.008, n=12)$.

\section{DISCUSSION}

In spite of the alkalinity of the clinker dust, its application resulted in a lower $\mathrm{pH}$ value of soil compared with control in this study. Long-term cement dust pollution in North-East Estonia has alkalized upper layers of soil (Kokk, 1991; Mandre, 1995). Loose wood ash, which is also alkaline and rich in base cations, decreases soil $\mathrm{pH}$ at $3-8 \mathrm{~cm}$ soil depth 71 days after the ash application at rates $2-8 \mathrm{tha}^{-1}$, while in upper layers the $\mathrm{pH}$ is increased (Eriksson et al., 1998). The decrease of the $\mathrm{pH}$ shortly after the treatment can be explained by the exchange between the base cations of the added compounds and the hydrogen ions at the soil cation exchange sites. The acids formed can migrate from the upper organic layer downwards. Wood ash increases the $\mathrm{pH}$ differences between soil layers shortly after application (Eriksson et al., 1998). No such differences between soil layers were found in the current trial. There was not even any significant difference in the variations in the soil $\mathrm{pH}$ between the sampling locations, although the sampling-scale heterogeneity in the dust cover was clearly visible at the time of the sample collection. The soil characteristics of the present experiment should be studied further. For example, the potential effect of clinker dust on the hydrogen ions in the soil cation exchange sites could be estimated by comparison of the measurements of the soil $\mathrm{pH}$ in water and $\mathrm{KCl}$.

The photosynthetic characteristics of needles were not affected. According to findings by St. Clair \& Lynch (2005), base cation fertilization on acid soil with imbalanced nutrient availability increases significantly photosynthetic electron transport rate in sugar maple, which is damaged by imbalanced nutrition, but not 
in red maple, which is a species tolerant to acidification and nutrient imbalances in soil. Scots pine is considered to be light demanding and tolerant to low soil nutrient availability. Thus, Scots pine should well adapt to the potential temporary acidification and associated changes in nutrient availability in soil at $1-5 \mathrm{~cm}$ depth after clinker dust application.

The concentration of hexoses was reduced by both clinker dust and fertilizer treatments. Since the effect of treatments on the soil $\mathrm{pH}$ was not coherent across the treatments, the observed effect on hexoses was more likely caused by nutrients in the clinker dust and the fertilizer than by the changes in the soil $\mathrm{pH}$. Earlier studies show that clinker dust and wood ash reduce the concentration of hexoses in pine and spruce needles and in willow leaves from July to September (Klõšeiko, 2003). In a previous study with the same stand, wood ash increased the $\mathrm{K}$ concentration in needles and improved the balance between $\mathrm{N}$ and $\mathrm{K}$ (Klõšeiko, 2006). Reduction in hexoses is found in cotton plants when potassium deficiency is corrected by potassium chloride (Pettigrew, 1999). The reduction in the concentration of hexose may indicate smaller invertase activity in needles of treated trees, because in K-deficient citrus leaves, the level of soluble carbohydrates and activity of invertase, which splits sucrose to hexoses, is higher (Lavon et al., 1995). Increased sucrose to hexoses ratio is found in leaves with high photosynthetic capacity, expressed by photosythesis rate at light saturation (Sims et al., 1999). In sugar maple, however, base cation amendment does not reduce the concentration of reducing carbohydrates (Liu et al., 1994).

In needles, the influence of treatments was constrained to the older generation. Older needles are more susceptible to $\mathrm{Mg}$ deficiency, since their physiological processes support young needles (Hallenbarter et al., 2002). Therefore, the larger alteration in the concentration of carbohydrates of older needles compared with new ones is a result that supports the hypothesis that treatments affected the nutrition of trees. In clinker dust, the highly soluble components that are required by plants could have an early influence. Fertilization studies in Finland have shown that $\mathrm{K}$ and the microelement $\mathrm{B}$ are easily leached out from wood ash and the influence of B can be readily observed on trees (Hytönen, 2003; Nieminen et al., 2005; Saarsalmi \& Tamminen, 2005). Boron deficiency causes great accumulation of sucrose, fructose, glucose, and starch in tobacco leaves (Camacho-Cristóbal \& González-Fontes, 1999). Since the fertilizer did not contain boron, further studies are required to clarify whether $\mathrm{B}$ can have the same effect on hexoses as $\mathrm{K}$, for example, by comparing treatments with potassium carbonate and boric acid or sodium tetraborate on needle carbohydrate concentrations.

The nitrogen release from the fertilizer was slow and the other elements were present also in clinker dust. In addition, the ratio of sucrose to hexoses was larger in the needles from longer shoots. Thus, the effect of the clinker dust lasting for a few months improved the nutrition of pines rather than changed the needle hexoses concentrations as a response of trees to potentially stressful alterations in the soil $\mathrm{pH}$. 


\section{ACKNOWLEDGEMENTS}

This study was financially supported by the Estonian Ministry of Education and Research (project No. 0432153s02) and the Estonian Science Foundation (grant No. 6026).

\section{REFERENCES}

Bergmeyer, H.-U., ed. 1988. Methods of Enzymatic Analysis. 3rd ed. Vol. 6. Wiley-VCH, Weinheim. Camacho-Cristóbal, J. J. \& González-Fontes, A. 1999. Boron defciency causes a drastic decrease in nitrate content and nitrate reductase activity, and increases the content of carbohydrates in leaves from tobacco plants. Planta, 20, 528-536.

Ericsson, T., Rytter, L. \& Vapaavuori, E. 1996. Physiology of carbon allocation in trees. Biomass Bioenergy, 11, 115-127.

Eriksson, H. M., Nilsson, T. \& Nordin, A. 1998. Early effects of lime and hardened and nonhardened ashes on $\mathrm{pH}$ and electrical conductivity of the forest floor, and relations to some ash and lime qualities. Scand. J. For. Res., Suppl. 2, 56-66.

Hallenbarter, D., Landolt, W., Bucher, J. B. \& Schütz, J.-P. 2002. Effects of wood ash and liquid fertilization on the nutritional status and growth of Norway spruce (Picea abies (L.) Karst.). Forstw. Cbl., 121, 240-249.

Hytönen, J. 2003. Effects of wood, peat and coal ash fertilization on Scots pine foliar nutrient concentrations and growth on afforested former agricultural peat soils. Silva Fenn., 37, 219 234.

Järvan, M. 2003. Mõnede kohalike lubiväetiste toimest põllukultuuridele ja mulla omadustele. Agraarteadus, 2, 63-68.

Kahl, J. S., Fernandez, I. J., Lindsey, E. R. \& Peckenham, J. 1996. Threshold application rates of wood ash to an acidic forest soil. J. Envir. Qual., 25, 220-227.

Klõšeiko, J. 2003. Carbohydrate Metabolism of Conifers in Alkalised Growth Conditions. Doctoral dissertation. Estonian Agricultural University, Tartu.

Klõšeiko, J. 2006. Early influence of wood ash application on the carbohydrate reserves and composition in needles of Scots pine (Pinus sylvestris). J. Sust. For. (in press).

Kokk, R. 1991. Muldade leelistumine Kirde-Eestis. In Mullakaitse probleeme Eestis, pp. 103-107. Valgus, Tallinn.

Lavon, R., Goldschmidt, E. E., Salomon, R. \& Frank, A. 1995. Effect of potassium, magnesium, and calcium deficiencies on carbohydrate pools and metabolism in citrus leaves. J. Am. Soc. Hort. Sci., 120, 54-58.

Liu, G., Côté, B. \& Fyles, J. W. 1994. Effects of base cation fertilization on the nutrient status, free amino acids and some carbon fractions of the leaves of sugar maple (Acer saccharum Marsh.). Plant Soil, 160, 79-86.

Mandre, M. 1995. Dust emission and deposition. In Dust Pollution and Forest Ecosystems. A Study of Conifers in an Alkalized Environment (Mandre, M., ed.). Publ. Inst. Ecol., 3, 18-22.

Manly, B. F. J. 1997. Randomisation, Bootstrap and Monte Carlo Methods in Biology. 2nd ed. Chapman \& Hall, London.

Marschner, H., Kirkby, E. A. \& Cakmak, I. 1996. Effect of mineral nutritional status on shoot-root partitioning of photoassimilates and cycling of mineral nutrients. J. Exp. Bot., 47, 1255-1263.

Maxwell, K. \& Johnson, G. N. 2000. Chlorophyll fluorescence - a practical guide. J. Exp. Bot., 51, 659-668.

Nieminen, M., Piirainen, S. \& Moilanen, M. 2005. Release of mineral nutrients and heavy metals from wood and peat ash fertilizers: field studies in Finnish forest soils. Scand. J. For. Res., 20, 146-153. 
Pettigrew, W. T. 1999. Potassium deficiency increases specific leaf weights and leaf glucose levels in field-grown cotton. Agron. J., 91, 962-968.

Saarsalmi, A. \& Tamminen, P. 2005. Boron, phosphorus and nitrogen fertilization in Norway spruce stands suffering from growth disturbances. Silva Fenn., 39, 351-364.

Sims, D. A., Cheng, W., Luo, Y. \& Seemann, J. R. 1999. Photosynthetic acclimation to elevated $\mathrm{CO}_{2}$ in a sunflower canopy. J. Exp. Bot., 50, 645-653.

St. Clair, S. B. \& Lynch, J. P. 2005. Base cation stimulation of mycorrhization and photosynthesis of sugar maple on acid soils are coupled by foliar nutrient dynamics. New Phytol., 165, 581-590.

St. Clair, S. B., Carlson, J. E. \& Lynch, J. P. 2005. Evidence for oxidative stress in sugar maple stands growing on acidic, nutrient imbalanced forest soils. Oecologia, 145, 258-269.

Steen, E. \& Larsson, K. 1986. Carbohydrates in roots and rhizomes of perennial grasses. New Phytol., 104, 339-346.

Total Starch Assay Procedure. 1998. Amyloglucosidase/ $\alpha$-amylase method. AACC Method 76.13. Megazyme International Ireland Ltd., Bray.

\title{
Klinkritolmu varane mõju hariliku männi okaste süsivesikute sisaldusele
}

\author{
Jaan Klõšeiko ja Mari Tilk
}

Klinkritolmu kasutamine metsamuldade töötlemiseks on perspektiivikas puude toitumistingimuste parandamise ja klinkritolmu kui heitme käitlemise seisukohalt. Kuna klinkritolm on leeliseline, siis vahetult pärast selle laotamist võivad suureneda $\mathrm{pH}$-väärtuse erinevused mullas, kus ülemistes kihtides $\mathrm{pH}$ suureneb ja alumistes väheneb. Mulla töötlemisega kaasneb puude toitumistingimuste järsk muutus ja pole teada, kas domineerivaks on stressi tekitavad $\mathrm{pH}$-muutused või klinkritolmus sisalduvad ja puude seisundit parandavad mineraalained. Artikli eesmärgiks on selgitada, milline on klinkritolmu varane mõju hariliku männi seisundile happelisel ja toitainevaesel mullal nõmmemännikus. Kaks kuud pärast klinkritolmu laotamist $\left(0,5 \mathrm{~kg} \mathrm{~m}^{-2}\right)$ mõõdeti mulla $\mathrm{pH}-\mathrm{d}(1-3$ ja $3-5 \mathrm{~cm}$ sügavusel). Puudel hinnati fotosünteesi omadusi klorofülli fluorestsentsi abil, võrsete kasvu ja süsivesikute sisaldust 1-aastastes ning jooksva aasta vanuseklassi okastes. Kontrollrühm kasvas töötlemata mullal. Klinkritolm avaldas olulist mõju ainult mulla reaktsioonile ja heksooside (glükoos + fruktoos) sisaldusele 1-aastastes okastes. Mulla $\mathrm{pH}$ oli klinkritolmuga töödeldud rühmas keskmiselt 0,5 ühikut väiksem kontrollrühma vastavast näitajast. Eeldatud $\mathrm{pH}$ erinevuste suurenemist kihtide ja proovivõtmiskohtade vahel ei leitud. Heksooside sisaldus okastes oli kontrollist väiksem. Arvestades, et sahharoosi ning heksooside suhe korreleerus võrsepikkusega ja võrreldes klinkritolmu mõju N-, P-, K- ja Mg-väetise mõjuga järeldati, et klinkritolmu summaarne toime esimeste kuude jooksul oli pigem puude seisundit parandav kui stressi põhjustav. 